\title{
Penyimpanan Suhu Rendah Berbagai Fase Hidup \\ Parasitoid: Pengaruhnya terhadap Parasitisasi dan Kebugaran Trichogrammatoidea armigera Nagaraja (Hymenoptera: Trichogrammatidae)
}

\section{MURTIYARINI, DAMAYANTI BUCHORI, DAN UTOMO KARTOSUWONDO}

\author{
Departemen Proteksi Tanaman, Fakultas Pertanian, Institut Pertanian Bogor \\ Jl. Kamper, Kampus Darmaga, IPB, Bogor \\ (diterima Januari 2006, disetujui Juli 2006)
}

\begin{abstract}
The effects of low temperatures on the fitness of Trichogrammatoidea armigera Nagaraja (Hymenoptera: Trichogrammatidae). T. armigera is one of the potential egg parasitoids. The aim of this research was to study the effects of low temperatures $\left(9^{\circ} \mathrm{C}\right.$ and $\left.15^{\circ} \mathrm{C}\right)$ on the fitness of T. armigera. The design of the experiments is a factorial design with two factors (temperature and age of parasitoid), with 10 replicates. Fitness were measured based on the survival, fertility, size, sex ratio, lifespan and fecundity. Result showed that the emergence of $T$. armigera was postponed by 2-5 days under low temperatures. Temperatures had a more significant effect than age of parasitoid. The postponement of adult emergence is very useful in regard to field application schedules. Percentage of adults emergence, sex ratio, egg productivity, fecundity tended to decrease under low temperatures, the length of female adult wings varied in each treatment and it tended to be shorter in $9^{\circ} \mathrm{C}$, while the width of female adult heads was almost similar in all treatment except in untreated control. These characters are very important in determining the fitness of the parasitoid in the field.
\end{abstract}

KEY WORDS: Trichogrammatoidea armigera, egg parasitoid, temperature, fitness, age.

\section{PENDAHULUAN}

Dampak negatif penggunaan pestisida seperti resistensi, resurgensi, berkurangnya populasi musuh alami dan residu pestisida di lingkungan telah menumbuhkan kesadaran akan pentingnya dilakukan pengendalian hayati sebagai cara pengendalian hama yang ramah lingkungan dan aman terhadap organisme bukan sasaran. Lingkungan hidup di sekitar manusia sesungguhnya telah menyediakan berbagai serangga sebagai predator atau parasitoid yang dapat digunakan untuk mengendalikan hama-hama di lahan pertanian. Kebutuhan parasitoid di lahan pertanian semakin meningkat. Namun keberadaan populasi parasitoid bervariasi di setiap daerah, bahkan di beberapa tempat populasi parasitoid tidak dalam jumlah cukup karena habitatnya terganggu setelah pembukaan lahan pertanian, praktek budidaya, dampak langsung pestisida dan menurunnya populasi hama sebagai inang (Meilin 1999). 
Untuk memenuhi kebutuhan tersebut, berbagai laboratorium penelitian telah banyak mengembangkan parasitoid. Parasitoid yang telah dikenal sejak tahun 1920 dan telah dibiakkan secara massal di laboratorium di Amerika adalah Trichogramma. Parasitoid ini bersifat polifag, mampu memarasit 10 ordo serangga, diantaranya adalah ordo-ordo hama penting seperti Lepidoptera, Coleoptera, Diptera, Heteroptera dan Neuroptera (Smith 1996). Trichogrammatoidea armigera adalah salah satu dari sekian banyak spesies Trichogramma, dan merupakan parasitoid yang dapat digunakan untuk mengurangi serangan hama penting Heliothis armigera, Plutella xylostella, Crocidolomia binotalis dan Scirpophaga incertulas pada berbagai tanaman yang bernilai ekonomi tinggi seperti padi, jagung, kapas, tembakau dan tebu (Majunath 1972, Nurindah \& Bindra 1989, Meilin 1999).

Berbagai penelitian telah dilakukan untuk memperbaiki kualitas dan melihat keefektifan Trichogramma di lapangan. Cuaca, umur tanaman, kualitas dan jumlah inang, pemangsaan, pestisida dan kualitas parasitoid adalah beberapa faktor yang mempengaruhi keberhasilan pelepasan dan tingkat kehilangan hasil (Smith 1996). Di Indonesia, pembiakan Trichogramma umum dilakukan pada inang alternatif, misalnya telur ngengat beras Corcyra cephalonica.

Pengiriman paket telur parasitoid dari laboratorium ke lahan pertani- an yang letaknya relatif jauh sering menemui berbagai kendala. Lama proses pengiriman dan waktu penetasan adalah dua hal yang harus diperhatikan. Biasanya imago Trichogramma akan muncul dari telur inang dalam waktu yang relatif cepat yaitu 7-9 hari setelah terparasit. Jika paket-paket telur tidak segera diaplikasikan, dikuatirkan imago akan muncul sebelum tiba di lapangan dan mati sebelum sempat menemukan inangnya. Oleh karena itu, diperlukan paket telur yang memiliki kualitas bagus dan dapat menunda kemunculannya sehingga waktu kemunculan dapat disesuaikan dengan waktu aplikasi di lapangan.

Penundaan waktu kemunculan diperoleh dengan perlakuan suhu rendah. Suhu rendah memberi pengaruh yang berbeda terhadap kualitas parasitoid, tergantung pada fase saat parasitoid tersebut diberi perlakuan (Gusman \& Petersen 1986, Smith 1996, Levie et al. 2000). Oleh karena itu perlu dipelajari pengaruh suhu rendah dan fase hidup parasitoid terhadap waktu kemunculan, tingkat parasitisasi dan kebugaran T. armigera.

\section{BAHAN DAN METODE}

Penelitian ini dilakukan di Laboratorium Pengendalian Hayati, Jurusan Hama dan Penyakit Tumbuhan, Institut Pertanian Bogor pada bulan Juni 2000 sampai Februari 2001 . 


\section{Pengadaan Telur Corcyra cephalonica}

Telur C. cephalonica sebanyak $0,25 \mathrm{ml}$ ( \pm 4500 butir) disebarkan ke dalam kotak plastik yang berisi $1 \mathrm{~kg}$ (setebal $2 \mathrm{~cm}$ ) campuran dedak pur ayam $2: 1$. Kotak tersebut kemudian ditutup dan disimpan dalam rak terlindung yang mempunyai sirkulasi udara yang baik. Kotak tidak boleh terbuka hingga 40 hari atau saat ngengat muncul. Prosedur ini diulangi hingga diperoleh jumlah yang cukup untuk persediaan selama percobaan.

Ngengat yang telah muncul dipindahkan ke dalam sangkar ngengat yang dialasi dengan kertas buram agar telur tidak tercecer. Dalam waktu semalam ngengat betina akan bertelur pada kawat kasa penutup sangkar. Ngengat betina dapat bertelur selama 4 hari. Setiap hari telur-telur dikumpulkan dengan kuas pada kertas buram. Telur-telur ini dipisahkan dari kotoran dan sisik ngengat. Telur yang telah kering dan bersih sebagian disebarkan pada campuran dedak pur ayam 2 : 1 untuk pengadaan telur selanjutnya dan sebagian dijadikan sebagai inang Trichogrammatoidea armigera. Telur yang akan digunakan dalam perlakuan disimpan dalam lemari pembeku (suhu $1^{0} \mathrm{C}$ ) selama 2 jam untuk mematikan embrio $C$. cephalonica sedangkan sisa telur yang belum terpakai disimpan di lemari pendingin ( suhu $5-10^{\circ} \mathrm{C}$ ).

\section{Pengadaan Trichogrammatoidea armigera}

Trichogrammatoidea armigera telah dibiakkan di Laboratorium Pengendalian Hayati, Jurusan Hama dan Penyakit Tumbuhan IPB dalam bentuk pias starter (pias-pias yang berisi telur inang terparasit) dengan ukuran 8 $\mathrm{cm} \times 0,5 \mathrm{~cm}$. Bagian yang berisi telur inang seluas $0,5 \mathrm{~cm} \times 0,5 \mathrm{~cm}$, dan mengandung 80-120 butir telur.

Pemarasitan T. armigera dilakukan pada telur $C$. cephalonica hasil pembiakan masal. Telur C. cephalonica ditaburkan pada bagian tengah pias berukuran $0,5 \mathrm{~cm} \times 0,5 \mathrm{~cm}$ yang telah diolesi perekat dari gom arab. Pias tersebut dimasukkan ke dalam tabung ge-las berisi pias starter sehari setelah parasitoid dewasa muncul (setelah terjadi kopulasi). Untuk makanan imago parasitoid diberikan madu 10\%, yang digoreskan pada dinding tabung dalam jumlah sedikit agar parasitoid tidak terperangkap.

Setiap pemaparan dilakukan selama 3 hari, hari pertama dan kedua masing-masing 2 lembar pias, hari ketiga 1 lembar pias. Dari 5 pias telur terparasit, 4 pias digunakan untuk perlakuan, sedangkan 1 pias lain digunakan sebagai starter pada pembiakan selanjutnya. Tabung yang berisi telur C. cephalonica terparasit disimpan di atas rak dengan penyinaran lampu TL 20 watt. 


\section{Penyimpanan Trichogrammatoi-} dea atmigera

Pias-pias hasil pengadaan $T$. armigera dipindahkan ke tabung gelas untuk perlakuan. Sebelumnya pias disimpan dalam suhu ruang selama 1 , 2, 4 dan 5 hari setelah pemarasitan, maksudnya agar parasitoid berada pada fase telur, larva, prapupa dan pupa saat perlakuan. Setelah jangka waktu tersebut, tabung pias disimpan selama 3 hari dalam lemari pendingin dengan suhu $9^{\circ} \mathrm{C}$ dan $15^{\circ} \mathrm{C}$, kemudian tabung-tabung gelas dikeluarkan dan dibiarkan pada suhu ruang. Pengamatan dilakukan setiap hari hingga ada tanda-tanda telur terparasit dan dilanjutkan sampai terjadi kemunculan imago parasitoid.

Imago yang muncul diparasitkan kembali ke telur C. cephalonica selama 24 jam. Setiap ulangan diambil 2 imago betina lalu dimasukkan ke dalam tabung berisi selembar pias telur C. cephalonica dan setiap hari pias diganti hingga imago mati untuk melihat tingkat parasitisasi, persen penetasan dan keperidian. Tanda parasitisasi diamati setelah tiga hari. Parasitisasi ditandai dengan perubahan warna telur menjadi kehitam-hitaman.

\section{Peubah Pengamatan}

Sesuai dengan tujuan penelitian, maka kebugaran dan keragaan $T$. armigera menjadi fokus pengamatan. Hal-hal yang menjadi peubah pengamatan adalah 1) lama perkem- bangan, dan 2) persentase kemunculan imago.

Lama perkembangan ditentukan dengan rumus :

$=\frac{\Sigma\left(\text { hari ke-n } \mathrm{X} \sum \text { imago hari ke-n) }\right.}{\Sigma \text { seluruh imago yang muncul }}$ X 100\%

Persentase kemunculan imago bertujuan untuk melihat tingkat ketahanan parasitoid dalam telur inang dan kemunculannya, dengan rumus :

$=\frac{\text { Jumlah imago yang muncul }}{\text { Jumlah telur terparasit }} \times 100 \%$

Peubah lain yang diamati adalah nisbah kelamin betina:jantan, ukuran imago betina, potensi produksi telur (dihitung dari keperidian dan sisa telur dalam ovari) dan lama hidup.

Rancangan percobaan yang digunakan adalah faktorial dalam rancangan acak lengkap. Sebagai perlakuan adalah faktorial dari suhu yaitu $9^{\circ} \mathrm{C}$ dan $15^{\circ} \mathrm{C}$ dengan fase hidup parasitoid yaitu telur (1 hari), larva (2 hari), prapupa (4 hari) dan pupa (5 hari). Untuk pembanding digunakan kontrol (suhu $20^{\circ} \mathrm{C}$ ). Setiap perlakuan terdiri atas 10 ulangan.

\section{HASIL DAN PEMBAHASAN}

\section{Hari Pertama Kemunculan Imago dan Lama Perkembangan Parasit- oid}

Penyimpanan pias-pias $T$. armigera pada suhu $9^{\circ} \mathrm{C}$ dan $15^{\circ} \mathrm{C}$ berpengaruh nyata terhadap lama 
perkembangan parasitoid. Kemunculan parasitoid dari telur inang tertunda selama 2-5 hari lebih lama dibanding kontrol (Tabel 1). Kemunculan imago paling banyak adalah pada hari pertama kemunculan dan menurun jumlahnya hingga hari ke 4 setelah kemunculannya pertama kali (Tabel 2). Interaksi antara faktor suhu dan fase hidup parasitoid berpengaruh nyata $(\mathrm{P}=0,0001)$ terhadap lama perkembangan. Pengaruh suhu lebih nyata daripada pengaruh fase hidup parasitoid. Apabila suhu agak tinggi $\left(15^{\circ} \mathrm{C}\right)$ perbedaan fase tidak mempengaruhi hari pertama kemunculan imago. Hari pertama kemunculan imago pada semua perlakuan fase parasitoid suhu $15^{\circ} \mathrm{C}$ adalah 10 hari. Pada suhu rendah $\left(9^{\circ} \mathrm{C}\right)$, perlakuan pada fase lanjut justru semakin menunda hari pertama kemunculan imago dan memperpanjang lama perkembangan.

Tabel 1. Pengaruh suhu rendah pada berbagai fase parasitoid terhadap lama perkembangan dan hari pertama kemunculan imago

\begin{tabular}{|c|c|c|c|c|c|c|}
\hline \multirow{2}{*}{ Fase } & \multicolumn{3}{|c|}{$\begin{array}{c}\left.\text { Lama perkembangan } \pm \mathrm{SB}^{\mathrm{a}}\right) \\
\text { (hari) }\end{array}$} & \multicolumn{3}{|c|}{ Hari pertama muncul } \\
\hline & $9^{\circ} \mathrm{C}$ & $15^{\circ} \mathrm{C}$ & K & $9^{\circ} \mathrm{C}$ & $15^{\circ} \mathrm{C}$ & K \\
\hline Telur & Tidak muncul & $10,47 \pm 0,25 \mathrm{e}$ & $9,01 \pm 0,43 \mathrm{ab}$ & - & 10 & 8 \\
\hline Larva & $11,86 \pm 0,46 \mathrm{c}$ & $11,03 \pm 0,27 \mathrm{~d}$ & $9,01 \pm 0,43 \mathrm{ab}$ & 11 & 10 & 8 \\
\hline Prapupa & $12,66 \pm 0,24 \mathrm{~b}$ & $10,37 \pm 0,21 \mathrm{e}$ & $9,01 \pm 0,43 \mathrm{ab}$ & 11 & 10 & 8 \\
\hline Pupa & $14,39 \pm 0,31 \mathrm{a}$ & $10,49 \pm 0,27 \mathrm{e}$ & $9,01 \pm 0,43 \mathrm{ab}$ & 11 & 10 & 8 \\
\hline
\end{tabular}

a) $\mathrm{SB}=$ Simpangan baku.

Angka yang diikuti oleh huruf yang sama berarti tidak berbeda nyata dengan uji selang berganda Duncan $\alpha=0,05$.

Tabel 2. Imago yang muncul pada hari 1 sampai hari 4 (dihitung dari hari pertama kemunculan) dan persentasenya terhadap total imago yang muncul

\begin{tabular}{lccccc}
\hline \hline Perlakuan & Hari 1 & Hari 2 & Hari 3 & Hari 4 & $\begin{array}{c}\text { Total Imago } \\
\text { yang muncul }\end{array}$ \\
\hline Kontrol & $17,5(35,6 \%)$ & $18,8(38,2 \%)$ & $8,6(17,5 \%)$ & $4,3(8,7 \%)$ & 49,2 \\
$9^{\circ} \mathrm{C}$ telur & 0 & 0 & 0 & 0 & 0 \\
& $9,8(42,8 \%)$ & $8,3(36,2 \%)$ & $4,5(19,7 \%)$ & $0,3(1,3 \%)$ & 22,9 \\
$9^{\circ} \mathrm{C}$ larva & $14(49 \%)$ & $10,3(36 \%)$ & $4,1(14,3 \%)$ & $0,2(0,7 \%)$ & 28,6 \\
$9^{\circ} \mathrm{C}$ prapupa & $3,9(20,4 \%)$ & $7,9(41,4 \%)$ & $4,5(23,6 \%)$ & $2,8(14,7 \%)$ & 19,1 \\
$9^{\circ} \mathrm{C}$ pupa & $38,4(58,4 \%)$ & $22,4(34 \%)$ & $4,7(7,1 \%)$ & $0,3(0,5 \%)$ & 65,8 \\
$15^{\circ} \mathrm{C}$ telur & $31(33,4 \%)$ & $35,6(38,4 \%)$ & $20,7(22,3 \%)$ & $5,5(5,9 \%)$ & 92,8 \\
$15^{\circ} \mathrm{C}$ larva & $60,8(65,8 \%)$ & $27,9(30,2 \%)$ & $3,7(4 \%)$ & 0 & 92,4 \\
$15^{\circ} \mathrm{C}$ prapupa & $73,5(61,8 \%)$ & $32,8(27,6 \%)$ & $12,1(10,2 \%)$ & $0,6(0,5 \%)$ & 119 \\
$15^{\circ} \mathrm{C}$ pupa & $27,7(40,8 \%)$ & $18,2(31,3 \%)$ & $7(13,2 \%)$ & $1,6(3,6 \%)$ & 54,4 \\
\hline Rata-rata & & & & & \\
\hline
\end{tabular}


Hal ini disebabkan oleh waktu yang lebih lama yang diperlukan oleh parasitoid yang telah diinkubasi pada suhu $9^{0} \mathrm{C}$ untuk beradaptasi kembali dengan suhu normal. Menurut Scott et al. (1997) penyesuaian ini dinamakan aklimasi suhu.

Parasitoid dalam fase telur memiliki ketahanan yang rendah terhadap suhu dingin. Embrio belum mempunyai organ-organ yang berfungsi untuk menyerap nutrisi dari telur inang sehingga suplai energi hanya sebatas suplai nutrisi dalam telur parasitoid itu sendiri, dan tidak cukup untuk menunjang penetasannya. Penurunan suhu penyimpanan hingga $9^{0} \mathrm{C}$ dapat mematikan embrio sehingga parasitoid tidak dapat muncul.

Pada fase larva, prapupa dan pupa, hari pertama kemunculan imago dan lama perkembangan semakin meningkat seiring dengan meningkatnya fase hidup parasitoid ketika mendapat perlakuan. Hari pertama kemunculan imago pada fase larva, prapupa dan pupa berurutan adalah 11, 12 dan 13 hari.

Kecuali fase telur, semakin awal parasitoid mendapat perlakuan suhu dingin semakin baik kemampuannya untuk segera beradapatasi terhadap tekanan suhu lingkungan. Ketika berada dalam tekanan suhu, parasitoid tidak aktif bermetabolisme dan siklus hidupnya tertunda. Setelah suhu dikembalikan pada keadaan normal, parasitoid melanjutkan siklus hidupnya. Seperti pada percobaan Djuwarso \&
Wikardi (1997), perkembangan praimago Trichogramma sp. dalam telur $C$. cephalonica mengalami dormansi pada suhu $7-10^{\circ} \mathrm{C}$ dan baru berlanjut setelah telur terparasit dikeluarkan dari lemari pendingin ke suhu kamar 27$30^{\circ} \mathrm{C}$ sehingga umur praimago bervariasi sesuai perlakuan yang dicobakan. Parasitoid paling aktif bermetabolisme pada saat fase larva dan dapat menyelesaikan siklus hidupnya lebih cepat karena fase larva lebih mudah beradaptasi dan segera aktif bermetabolisme begitu keluar dari cekaman suhu.

\section{Persentase Kemunculan Imago}

Secara umum, persentase kemunculan imago parasitoid dari telur inang mengalami penurunan setelah terjadi penurunan suhu penyimpanan. Suhu dan fase hidup berpengaruh nyata $(\mathrm{P}=0,0001)$ terhadap persentase kemunculan imago. Begitu juga dengan interaksi antara kedua faktor tersebut juga berpengaruh nyata $(\mathrm{P}=0,0001)$ terhadap hasil (Tabel 3).

Khusus pada perlakuan suhu $9^{0} \mathrm{C}$ fase telur, parasitoid sama sekali tidak muncul. Kondisi telur inang mengkerut dan tidak menghitam sehingga tidak dapat diketahui jumlah telur inang terparasit.

Penurunan suhu hingga tingkat tertentu pada telur dapat merusak komponen nutrisi pembentuk embrio. Ada 3 jenis penghambatan yang terjadi akibat penurunan suhu, yaitu perusakan komponen nutrisi embrio sehingga 
telur parasitoid tidak dapat menetas (seperti terjadi pada perlakuan $9^{\circ} \mathrm{C}$ fase telur), penghambatan metabolisme pada parasitoid praimago (fase larva dan prapupa) dan penghambatan kemunculan imago dari telur inang (fase pupa). Perlakuan suhu $15^{\circ} \mathrm{C}$ tidak terlalu menekan perkembangan parasitoid. Hal ini terlihat dari persentase kemunculan imago yang relatif tinggi, bahkan pada fase larva persentase kemunculan imago lebih tinggi daripada kontrol.

Fase larva dan prapupa adalah fase terbaik pada penyimpanan $9^{\circ} \mathrm{C}$, sedangkan pada fase pupa persentase kemunculan imago sangat rendah. Hal ini berhubungan dengan lama perkembangan parasitoid dan hari pertama kemunculan imago yang relatif lama. Pada perlakuan suhu $9^{0} \mathrm{C}$ fase pupa mempunyai lama perkembangan dan hari pertama kemunculan imago paling lama yang berakibat pada persentase kemunculan imago sangat rendah (Tabel 3). Menurut Hagen
(1960 dalam Stehr 1987), serangga endoparasitoid mengambil oksigen dari cairan telur inang di sekitar tubuhnya melalui integumen, dengan demikian penundaan kemunculan yang terlalu lama menyebabkan parasitoid kehabisan oksigen dan mati sebelum muncul dari telur inang.

\section{Nisbah Kelamin Imago Parasitoid}

Persentase imago betina dari total imago menurun seiring dengan penurunan suhu perlakuan (Tabel 4). Nisbah kelamin kontrol tidak berbeda nyata dengan angka yang diperoleh dari hasil perlakuan suhu $15^{\circ} \mathrm{C}$.

Pengaruh suhu menghasilkan nilai nisbah kelamin yang berbeda nyata $(\mathrm{P}=0,0001)$, begitu juga dengan pengaruh fase hidup parasitoid adalah nyata $(\mathrm{P}=0,0001)$. Fase larva menghasilkan persentase betina paling tinggi pada kedua tingkat suhu penyimpanan. Interaksi antara kedua faktor tidak berpengaruh nyata pada hasil $(\mathrm{P}=1,0000)$ (Tabel 5).

Tabel 3. Pengaruh suhu rendah pada berbagai fase parasitoid terhadap persentase kemunculan imago

\begin{tabular}{lccc}
\hline \hline \multirow{2}{*}{ Fase } & \multicolumn{4}{c}{ Persentase kemunculan imago \pm SB ${ }^{\mathrm{a}}$} \\
\cline { 2 - 4 } & $9^{0} \mathrm{C}$ & $15^{\circ} \mathrm{C}$ & Kontrol \\
\hline Telur & $0 \mathrm{f}$ & $82,47 \pm 5,52 \mathrm{~cd}$ & $89,67 \pm 4,46 \mathrm{bc}$ \\
Larva & $77,91 \pm 9,83 \mathrm{dc}$ & $96,96 \pm 1,86 \mathrm{a}$ & $89,67 \pm 4,46 \mathrm{bc}$ \\
Prapupa & $77,14 \pm 16,03 \mathrm{~d}$ & $87,79 \pm 6,34 \mathrm{bc}$ & $89,67 \pm 4,46 \mathrm{bc}$ \\
Pupa & $41,09 \pm 24,74 \mathrm{e}$ & $91,58 \pm 4,33 \mathrm{~b}$ & $89,67 \pm 4,46 \mathrm{bc}$ \\
\hline
\end{tabular}

a) $\mathrm{SB}=$ Simpangan baku

Angka yang diikuti oleh huruf yang sama berarti tidak berbeda nyata dengan uji selang berganda Duncan $\alpha=0,05$. Analisis data dilakukan setelah data ditransformasikan pada Arch sin.

Pengaruh interaksi kedua faktor nyata terhadap hasil $(\mathrm{P}=0,0001)$ 
Jenis kelamin parasitoid sangat ditentukan oleh ada tidaknya pembuahan telur oleh sperma sebelum imago betina meletakkan telurnya pada inang. Menurut Godfray (1994), dalam laboratorium pembiakan, parasitoid Hymenoptera yang meletakkan telurnya sebelum kawin akan menghasilkan telur-telur jantan. Pada penelitian ini, pias-pias yang mendapat perlakuan diperoleh dari pias stok yang diasumsikan mempunyai kualitas yang sama, telur-telur yang diletakkan diasumsikan mempunyai nisbah kelamin yang sama dengan kontrol.

Nisbah kelamin dipengaruhi oleh suhu. Ketahanan parasitoid jantan dan betina berbeda terhadap suhu dingin. Larva, prapupa, pupa dan imago betina diduga mempunyai ketahanan lebih rendah dibanding dengan jantan sehingga kemunculannya dari telur inang terhambat. Hal ini terlihat dari nisbah kelamin betina:jantan dan persentase betina yang rendah setelah mendapat perlakuan suhu $9^{0} \mathrm{C}$. Menurut King (1998 dalam Godfray 1994), pada kebanyakan parasitoid, terutama pada spesies yang berdiapause, imago jantan lebih cepat perkembangannya daripada betina. Jika lama kemunculan imago ini dihubungkan dengan suplai oksigen dalam telur inang, maka keterlambatan tersebut dapat menyebabkan kematian.

\section{Potensi Produksi Telur}

Potensi produksi telur adalah jumlah telur yang diletakkan (keperidian) ditambah dengan jumlah telur yang tersisa dalam ovari. Imago dari kontrol dan perlakuan suhu $15^{\circ} \mathrm{C}$ mempunyai potensi produksi telur lebih tinggi (19-32 butir) daripada

Tabel 4. Pengaruh suhu rendah terhadap nisbah kelamin imago

\begin{tabular}{lc}
\hline \hline Perlakuan & Nisbah kelamin jantan : betina \\
\hline Kontrol & $1: 1,36$ \\
$9^{\circ} \mathrm{C}$ & $1: 0,81$ \\
$15^{\circ} \mathrm{C}$ & $1: 1,10$ \\
\hline
\end{tabular}

Pengaruh suhu nyata $(\mathrm{P}=0,0001)$

Tabel 5. Pengaruh fase hidup terhadap nisbah kelamin

\begin{tabular}{lc}
\hline \hline Perlakuan & Nisbah kelamin jantan : betina \\
\hline Kontrol & $1: 1,36$ \\
Telur & $1: 1,11$ \\
Larva & $1: 1,01$ \\
Prapupa & $1: 1,18$ \\
Pupa & $1: 1,10$ \\
\hline
\end{tabular}

Pengaruh fase hidup nyata $(\mathrm{P}=0,0001)$ 
perlakuan suhu $9^{\circ} \mathrm{C}$ (9-14 butir). Pengaruh suhu nyata pada kedua taraf perlakuan ( $\mathrm{P}=0,0001)$ (Tabel 6 dan 7). Seperti halnya suhu, fase hidup parasitoid berpengaruh nyata $(\mathrm{P}=0,0001)$ terhadap potensi produksi telur, sedangkan pengaruh interaksi antara keduanya tidak nyata.

Potensi produksi telur lebih dipengaruhi oleh keberhasilan perkembangan sel telur. Wigglesworth (1974) menyatakan ketika suhu turun, lebih banyak energi yang dibutuhkan untuk menghasilkan pertumbuhan dalam jumlah yang sama seperti pada suhu normal. Artinya, dengan jumlah energi yang sama dengan suhu normal, pertumbuhan yang dicapai pada suhu dingin lebih rendah. Persediaan energi yang dimiliki oleh parasitoid tidak seluruhnya dialokasikan untuk perkembangan oosit, tetapi juga untuk metabolisme tubuh yang lain. Akibatnya, jumlah telur yang berpotensi untuk diletakkan oleh imago betina menurun.

Suhu yang terlalu dingin dapat merusak telur yang ada dalam ovari imago betina. Wigglesworth (1974) mengemukakan bahwa sel atau jaringan yang berada pada suhu yang sangat dingin dapat mengalami dehidrasi dan mengkerut. Kondisi tersebut yang mungkin terjadi pada sebagian telur dalam tubuh imago betina sehingga tidak dapat dikenali lagi dalam wujud telur. Hal inilah yang menurunkan jumlah sisa telur dalam ovari dan menurunkan nilai potensi produksi telur.

T. armigera meletakkan telur paling banyak pada hari pertama dan kedua setelah kemunculannya dari telur inang. Dengan demikian, lama hidup lebih dari 2 hari tidak terlalu berpengaruh pada keperidian. Sebaliknya, lama hidup imago kurang dari 2 hari sangat berpengaruh terhadap keperidian karena imago telah mati pada saat masih mampu untuk meletakkan telur dalam jumlah banyak.

\section{Ukuran Imago Betina dan Hubungannya dengan Kemampuan Reproduksi}

Imago yang muncul dari kontrol mempunyai ukuran kepala sedikit lebih besar daripada perlakuan lainnya. Lebar kepala imago parasitoid hasil perlakuan pada semua fase dan suhu mempunyai nilai yang tidak berbeda nyata (Tabel 8).

Tabel 6. Pengaruh suhu terhadap potensi produksi telur imago betina

\begin{tabular}{lc}
\hline \hline Perlakuan & Produksi telur imago betina. \\
\hline Kontrol & 23,85 \\
$9^{\circ} \mathrm{C}$ & 10,5 \\
$15^{\circ} \mathrm{C}$ & 24,44 \\
\hline
\end{tabular}

Pengaruh suhu nyata $(\mathrm{P}=0,0001)$ 
Tabel 7. Pengaruh fase hidup terhadap potensi produksi telur imago betina.

\begin{tabular}{lc}
\hline \hline Perlakuan & Produksi telur imago betina. \\
\hline Kontrol & 23,83 \\
Telur & 8,13 \\
Larva & 2,55 \\
Prapupa & 20,33 \\
Pupa & 14,13 \\
\hline
\end{tabular}

Pengaruh fase hidup nyata $(\mathrm{P}=0,0001)$

Panjang sayap mempunyai nilai yang berbeda nyata pada hampir semua perlakuan. Faktor suhu dan fase hidup parasitoid berpengaruh nyata $(\mathrm{P}=0,0001)$, begitu juga dengan interaksi antara kedua faktor tersebut $(\mathrm{P}=0.0001)$. Sayap imago betina relatif lebih pendek pada perlakuan suhu $9^{\circ} \mathrm{C}$ daripada suhu $15^{\circ} \mathrm{C}$ (Tabel 9).

Ukuran tubuh (panjang sayap dan lebar kepala) imago betina dari semua perlakuan tidak menunjukkan korelasi yang tegas terhadap keperidian dan potensi produksi telur, tetapi terdapat kecenderungan bahwa semakin besar ukuran kepala dan sayap maka semakin baik kemampuan reproduksinya.

Suhu dingin menghambat perolehan nutrisi secara optimal oleh parasitoid karena terjadinya kerusakan nutrisi inang dan penghambatan fungsi metabolisme serangga dalam hal absorbsi. Sebagai akibatnya, ukuran tubuh parasitoid dewasa pada suhu rendah menjadi lebih kecil daripada keadaan normal dan perkembangan sel-sel telur dalam ovari imago betina tidak optimal sehingga mempengaruhi potensi produksi telur.
Ada kecenderungan bahwa semakin besar ukuran tubuh imago betina maka semakin baik kemampuan reproduksinya. Akan tetapi korelasi antara ukuran tubuh dengan kemampuan reproduksi tersebut tidak tegas. Rusaknya telur dalam ovari imago betina akibat suhu dingin dapat dijadikan alasan penyebab berkurangnya keperidian. Pengaruh suhu lebih utama daripada pengaruh ukuran tubuh sehingga ukuran tubuh betina tidak selalu menentukan potensi produksi telur dan keperidian (Blackburn 1991 dalam Quicke 1997). Menurut Bourchier et al. (1993), kebiasaan parasitoid di lapangan seperti penerimaan inang dan kemampuan mencari inang dapat mengurangi dugaan bahwa keperidian hanya dapat dilihat dengan melihat ukuran tubuh parasitoid. Ukuran tubuh yaitu panjang sayap dan lebar kepala menjadi salah satu parameter keberhasilan pelepasan Trichogramma di lapangan karena berhubungan dengan kemampuan penerbangan, pencarian inang dan kemampuan menghadapi situasi alam yang 
Tabel 8. Pengaruh suhu rendah pada berbagai fase parasitoid terhadap lebar kepala imago betina

\begin{tabular}{lccc}
\hline \hline & \multicolumn{3}{c}{ Lebar kepala $\left.(\mathrm{mm}) \pm \mathrm{SB}^{\mathrm{a}}\right)$} \\
\cline { 2 - 4 } Fase & $9^{0} \mathrm{C}$ & $15^{\circ} \mathrm{C}$ & Kontrol \\
\hline Telur & Tidak ada imago & $0,1864 \pm 0,0103 \mathrm{~b}$ & $0,2050 \pm 0,0250 \mathrm{a}$ \\
Larva & $0,1720 \pm 0,0175 \mathrm{~b}$ & $0,1864 \pm 0,0131 \mathrm{~b}$ & $0,2050 \pm 0,0250 \mathrm{a}$ \\
Prapupa & $0,1737 \pm 0,0147 \mathrm{~b}$ & $0,1746 \pm 0,0127 \mathrm{~b}$ & $0,2050 \pm 0,0250 \mathrm{a}$ \\
Pupa & $0,1757 \pm 0,0202 \mathrm{~b}$ & $0,1803 \pm 0,0089 \mathrm{~b}$ & $0,2050 \pm 0,0250 \mathrm{a}$ \\
\hline
\end{tabular}

a) $\mathrm{SB}=$ Simpangan baku

Tabel 9. Pengaruh suhu rendah pada berbagai fase parasitoid terhadap panjang sayap imago betina

\begin{tabular}{lcll}
\hline \hline & \multicolumn{3}{c}{ Panjang sayap $\left.(\mathrm{mm}) \pm \mathrm{SB}^{\mathrm{a}}\right)$} \\
\cline { 2 - 4 } Fase & \multicolumn{1}{c}{$15^{0} \mathrm{C}$} & \multicolumn{1}{c}{ Kontrol } \\
\hline Telur & Tidak ada imago & $0,4364 \pm 0,0112 \mathrm{bcd}$ & $0,4588 \pm 0,0309 \mathrm{ab}$ \\
Larva & $0,4138 \pm 0,0305 \mathrm{de}$ & $0,4722 \pm 0,0207 \mathrm{a}$ & $0,4588 \pm 0,0309 \mathrm{ab}$ \\
Prapupa & $0,4241 \pm 0,0201 \mathrm{cde}$ & $0,4449 \pm 0,0112 \mathrm{bc}$ & $0,4588 \pm 0,0309 \mathrm{ab}$ \\
Pupa & $0,4081 \pm 0,0392 \mathrm{e}$ & $0,4377 \pm 0,0208 \mathrm{bcd}$ & $0,4588 \pm 0,0309 \mathrm{ab}$ \\
\hline
\end{tabular}

a) $\mathrm{SB}=$ Simpangan baku

Angka yang diikuti oleh huruf yang sama berarti tidak berbeda nyata dengan uji selang berganda Duncan $\alpha=0,05$. Pengaruh interaksi kedua faktor nyata terhadap hasil $(\mathrm{P}=0,0001)$

tidak menguntungkan seperti angin kencang dan curah hujan, untuk memenangkan kompetisi dengan spesies lain yang ukuran tubuhnya lebih kecil.

Penundaan kemunculan imago sangat bermanfaat untuk pengaturan jadwal aplikasi di lapangan, khususnya untuk daerah yang letaknya jauh dari laboratorium pembiakan dan membutuhkan waktu beberapa hari untuk pengiriman pias-pias parasitoid. Lama penundaan yang berbeda merupakan alternatif pilihan yang dapat diambil sesuai dengan kebutuhan.

Namun demikian, hasil yang baik tidak hanya didasarkan pada hari kemunculan imago dan lama perkembangan. Faktor-faktor yang merupakan ciri kebugaran juga harus dipertimbangkan. Persentase kemunculan imago, nisbah kelamin betina: jantan dan potensi produksi telur sangat penting dalam menentukan jumlah imago parasitoid betina dan jumlah telur potensial yang akan diproduksi oleh parasitoid, didukung oleh keperidian, lama hidup dan ukuran imago betina yang mempengaruhi kemampuan imago betina mencari inang. Semua faktor di atas akhirnya menentukan jumlah telur inang yang dapat diparasit oleh $T$. armigera. 
Kebugaran T. armigera semakin baik jika siklus hidupnya diselesaikan pada kondisi lingkungan yang optimum, salah satunya adalah suhu. Pada penelitian ini perlakuan suhu $15^{\circ} \mathrm{C}$ menghasilkan T. armigera dengan kebugaran yang lebih baik daripada perlakuan $9^{0} \mathrm{C}$ karena suhu $15^{\circ} \mathrm{C}$ mendekati suhu kontrol $\left(20^{\circ} \mathrm{C}\right)$. Potensi produksi telur, keperidian dan lama hidup saling mendukung dalam menentukan jumlah telur parasitoid yang dapat diletakkan.

Penyimpanan parasitoid pada suhu rendah hendaknya juga memperhatikan keberhasilan pelepasannya di lapangan. Trichogramma bertahan baik pada suhu lingkungan yang mirip dengan suhu saat pembiakan. Parasitoid hasil penyimpanan suhu rendah umumnya lebih mampu dalam mengendalikan hama-hama tanaman hortikultura yang umumnya ditanam pada dataran tinggi yang bersuhu dingin dan masih aktif terbang pada suhu yang lebih tinggi. Menurut Smith \& Hubbes 1986 dalam Prasad et al. 1999, T. minutum yang dibiakkan pada suhu $15^{\circ} \mathrm{C}$ lebih aktif lompat dan terbang pada suhu $25^{\circ} \mathrm{C}$ daripada T. minutum hasil pembiakan pada suhu yang lebih tinggi. Adaptasi yang baik ini karena organisme-organisme ektotermis, seperti Trichogramma, menjalani suatu kenaikan tingkat metabolisme saat dibiakkan pada suhu rendah (Burnel et al. 1991 dalam Prasad et al. 1999)

\section{KESIMPULAN DAN SARAN}

Trichogrammatoidea armigera mengalami penundaan kemunculan selama 2-5 hari setelah penyimpanan pada suhu rendah. Pada perlakuan suhu $9^{0} \mathrm{C}$ fase larva, prapupa dan pupa kemunculan imago berturut-turut tertunda 3, 4 dan 5 hari. Semakin awal parasitoid mendapat perlakuan maka semakin baik kemampuan adaptasinya sehingga dapat menyelesaikan siklus hidupnya lebih cepat. Pada fase telur tidak terjadi kemunculan imago. Lama perkembangan parasitoid relatif seragam pada perlakuan $15^{\circ} \mathrm{C}$ meskipun juga mengalami penundaan selama dua hari. Penundaan kemunculan imago sangat bermanfaat untuk pengaturan jadwal aplikasi di lapang.

Secara umum perlakuan suhu $15^{\circ} \mathrm{C}$ fase prapupa menghasilkan kualitas parasitoid yang relatif lebih baik daripada perlakuan yang lain, yaitu persentase kemunculan imago $87,79 \%$, potensi produksi telur 27,45, dan nisbah kelamin betina:jantan 1,51: 1 .

Di lapangan, keefektifan $T$. armigera hasil penyimpanan suhu dingin masih menjadi pertanyaan. Oleh karena itu masih diperlukan uji lapangan pelepasan $T$. armigera hasil penyimpanan suhu dingin dengan memperhatikan aspek-aspek lapang yang komplek antara lain proses transportasi, cuaca, jenis pertanaman, keberadaan inang, dan pengaruh pestisida. 


\section{DAFTAR PUSTAKA}

Bourchier RS, Smith SM, Song SJ. 1993. Host acceptance and parasitoids size as predictors of parasitoid quality for massreared Trichogramma minutum. Biol Control 3: 135-139.

Djuwarso T, Wikardi EA. 1997. Perbanyakan Trichogramma sp. parasitoid telur Cricula trifenestrata Helf pada jambu mete. J Littri $3(3)$.

Godfray HCJ. 1994. Parasitoids: behavioral and evolutionary ecology. Princeton University Press. New Jersey, USA.

Gusman DR, Petersen JJ. 1986. Cold acclimation and prolonged low temperature furvival of filth fly parasites (Hymenoptera : Pteromalidae). Environ Entomol 15 (4).

Levie A, Dogot P, Hance T. 2000. Cold shock versus acclimation effect on survival of cold stored parasitoid mummies of ages. Antonie van Leeuwenhoek symposium, Haarlen, The Netherlands.

Manjunath TM. 1972. Biological studies on Trichogrammatoidea armigera Nagaraja : a new dimorphic egg parasite of Heliothis armigera (Hubner) in India. Entomophaga $17(2)$.

Meilin A. 1999. Keragaman karakter morfologi dan genetik populasi telur Trichogrammatoidea spp. (Hymenoptera :
Trichogrammatidae) dari daerah geografis berbeda di Pulau Jawa. [Tesis]. Program Pascasarjana, Institut pertanian Bogor.

Nurindah, Bindra OS. 1989. Studies on Trichochogramma spp. (Hymenoptera: Trichogrammatidae) in the control of Heliothis armigera (Hubner) (Lepidoptera : Noctuidae). Biotrop Special Publication No. $36: 165-173$.

Prasad RP, Roitberg BD, Henderson D. 1999. The effect of rearing temperature on flight initiation of Trichogramma sibericum Sorkina at ambient temperatures. Biol Control 16 : 291-298.

Quicke DLJ. 1997. Parasitic wasps. Chapman and Hall Publ. London, Britain

Scott M, Berrigan D, Hoffmann A. 1997. Cost and benefits of acclimation to elevated temperature in Trichogramma carverae. Entomol Experimentalist et Applicata 85 : 211-219. Kluwer Academic Publishers. Belgium.

Smith SM. 1996. Biological control with Trichogramma : advances, successes and potential of their use. In Mittler TE, Padovsky FS, Resh VH ( Editor). Annu Rev Entomol 41: 375-406.

Stehr FW. 1987. Immature insects. Kendall / Hunt Publishing Company, USA.

Wigglesworth VB. 1974. The principles of insect physiology. The $7^{\text {th }}$ Edition. London Chapman and Hall. Britain. 